\title{
Primers application with the Tso31 gene target in the molecular identification of Taenia solium
}

\author{
Nur Habibah, Heri Setiyo Bekti", Ni Wayan Rika Kumara Dewi, Luh Putu Rinawati, \\ Burhannuddin, Aprilia Rakhmawati
}

Department of Medical Laboratory Technology, Poltekkes Kemenkes Denpasar, Indonesia

*Corresponding author: herisetiyob7@gmail.com

\begin{abstract}
Background: taeniasis is a zoonotic disease caused by Taenia spp. Human taeniasis caused by Taenia solium can be acquired after consumption of raw insufficiently cooked infected pork meat. Pigs are intermediate host for T.solium. Pigs acquired this infection by eating human feces that contained T.solium eggs. Pigs infected with T.solium can be transmitted to humans. Purposes: identification of T.solium in pig is important because it is indicator of T.solium transmission. Microscopic examination of T.solium eggs is considered less effective and efficient so that many other methods are developed for T.solium detection such as molecular and immunology. Method: This method used specific primer which can detect the Tso31 gene in T.solium. Tso31 gene is one of the most promising antigens to differentiate T.solium from T.saginata. Pig feces samples were taken by random sampling technique from 7 pig farms in Denpasar. Result: from the 30 samples, we found one sample that which gave a single amplification product of $234 \mathrm{bp}$. This indicates that the pig farms in Denpasar have been infected with T.solium. Conclusion: it is necessary to do meat inspection properly in the market as well as health education about the dangers and impacts of T.solium infection in the community.
\end{abstract}

Keywords: taeniasis, taenis solium, tso31 gene target

\section{INTRODUCTION}

Taeniasis is a zoonotic disease caused by Taenia spp. There are three species which can infect humans: Taenia saginata, Taenia solium, and Taenia asiatica. This disease is still endemic in the developing country and has a great importance for public health (1). The human is the definitive host for these three species and harbour the adult tapeworm in the small intestine. Cattle are the intermediate host for $T$ saginata, while the pigs are the intermediate host for T.solium and $T$ asiatica (2).
Human taeniasis/cysticercosis caused by T.solium can be acquired after consumption of raw insufficiently cooked infected pork meat, which subsequently develops to the adult tapeworm in the human small intestine (3). Taeniasis in humans can manifest as asymptomatic or minimally symptomatic intestinal carriage or as infection with cysticerci, predominantly in the eyes, muscle, subcutaneous, and neural tissues (4).

Neurocysticercosis is an infection caused by T.solium. Neurocysticercosis is considered to be the most common cause of acquired epilepsy 
and is thought to contribute up to $30 \%$ of epilepsy cases in the endemic areas $(5,6)$.

T.solium has a global distribution with significant economic and public health impacts. The impacts of T.solium causes important economic losses, especially in the meat sector, and represent a food safety issue rather than a serious public health problem especially for the pork eating populations, as taeniasis rarely causes serious clinical signs and symptoms $(2,7)$.

Pig is the natural animal intermediate host for T.solium. Pigs being coprophagic animals, usually acquired infection by direct consumption of human feces that contain T.solium eggs, or indirectly via contaminated water, vegetation/foods, or soil. When ingested, the eggs liberate hexacanth embryos or oncospheres in the gastrointestinal tract (3).

Animal husbandry and farming practices in Indonesia especially in Bali still remain simple and close to residential areas. Although the breeders raise pigs in pens. However, sanitation and cleanliness of the cage is not carried out properly. Balinese people's habit of eating raw pork can also be a source of T.solium infection.

Moreover, small-scale pig husbandry in Bali has become one of the major sources of income. Consumption of uninspected pig meat is the major source of human T.solium taeniasis and consequently, a major risk factor for human and pig (8). Identification of T.solium in pigs is important because it is an indicator of T.solium transmission and the risk of taeniasis/cysticercosis in the carrier or the immediate environment $(9,10)$.

For many years, the laboratory diagnosis of taeniasis has been based on the detection of eggs by microscopic examination from fecal samples, which still remains the routine laboratory diagnosis in most laboratories. Recent studies reveal that microscopic examination alone is not reliable to differentiating the species of Taenia (11). Microscopic examination also has low sensitivity and can not distinguish the morphology of T.solium and $T$ saginata eggs (10).

Newer methods like immunological, and molecular methods have been used to detect T.solium, while a combination of two or more methods appears to provide higher sensitivity (3). Up to now the only reliable technique to distinguish Taenia eggs is PCR (8).

Molecular biology has been employed to detect parasites in order to enhance the identification and characterization of parasites such as T.solium. The goal of this study was to detect T.solium in pigs from fecal samples using PCR method with $h$ specific primers which can detect the Tso31 gene in T solium.

\section{METHODS}

This study was used to detect taeniasis in pig farms in Denpasar, Bali. The population in this study were pig farms in Denpasar city. There are seven pig farms in Denpasar, Bali. The owner who has agreed to the informed consent is followed up by taking 30 samples of pig feces.

The samples was obtained using a random sampling technique from 7 pig farms in Denpasar. Sufficient pork feces were taken using a sterile stick. Feces samples were added with $2.5 \%$ Potassium dichromate, in a ratio of 1:2. The sample was placed in the sample container that has been provided and closed properly and stored at the room temperature. Stool samples were preserved with $2.5 \%$ potassium dichromate added with aquadest. The samples were centrifuge at $14,000 \mathrm{rpm}$ for 10 minutes and the supernatant was discarded. After that, the samples were washed with aquadest three times (7). DNA from stool samples can be extracted using QIAamp-Fast DNA Stool Mini Kit $(10,11)$. 
In this study, we used nested PCR assay was used by Mayta et al to detect the T.solium oncosphere protein Tso31 (7). The first master mixture of PCR was performed in a total volume consisting of $25 \mu \mathrm{l}$, containing of $3 \mathrm{mM}$ $\mathrm{MgCl}_{2}, 200 \mu \mathrm{M}$ deoxynucleoside triphosphate, $0.2 \mu \mathrm{g} / \mu \mathrm{l}$ BSA, $0.8 \mu \mathrm{M}$ primer $1,0.125 \mathrm{U}$ Taq Polymerase, and $2.0 \mu \mathrm{l}$ of sample. PCR amplification was carried out in Biometra TAdvanced. The first PCR amplification utilized an initial denaturation step at $95^{\circ} \mathrm{C}$ for 3 min, followed by 25 amplification cycles, each consisting of a denaturation step at $95^{\circ} \mathrm{C}$ for 30 $\mathrm{s}$, annealing at $55^{\circ} \mathrm{C}$ for $30 \mathrm{~s}$, and extension at $72^{\circ} \mathrm{C}$ for $1 \mathrm{~min}$. The final extension at $72^{\circ} \mathrm{C}$ for $10 \mathrm{~min}$. Subsequently, PCR-amplified products were electrophoresed using 2\% agarose gel. The gels were stained with ethidium bromide $(10 \mu \mathrm{g} / \mathrm{ml})$ for $10 \mathrm{~min}$. The stained gels were observed in a transluminator and documented.

The second PCR was carried out in Biometra TAdvanced TADVANCED. The second master mixture of PCR was performed in a total volume of $25 \mu \mathrm{l}$, containing $2.5 \mathrm{mM}$ $\mathrm{MgCl}_{2}, 200 \mu \mathrm{M}$ deoxynucleoside triphosphate, $0.2 \mu \mathrm{g} / \mu \mathrm{l} \mathrm{BSA}, 0.8 \mu \mathrm{M}$ primer $1,0.125 \mathrm{U}$ Taq Polymerase, and $2.0 \mu \mathrm{l}$ of sample. The second PCR amplification consisted of an initial denaturation step at $95^{\circ} \mathrm{C}$ for $3 \mathrm{~min}$, followed by 25 amplification cycles, each consisting of a denaturation step at $95^{\circ} \mathrm{C}$ for $30 \mathrm{~s}$, annealing at $60^{\circ} \mathrm{C}$ for $30 \mathrm{~s}$, and extension at $72^{\circ} \mathrm{C}$ for 1 min. The final extension at $72^{\circ} \mathrm{C}$ for $10 \mathrm{~min} .2$ $\mu \mathrm{l}$ of PCR-amplified products were electrophoresed using $2 \%$ agarose gel. The gels were stained with ethidium bromide $(10 \mu \mathrm{g} / \mathrm{ml})$ for $10 \mathrm{~min}$. The stained gels were observed in a transluminator and documented.

\section{RESULT}

From 30 samples, we obtained one sample which gave a single amplification product of 234 bp (Figure 1 and 2)

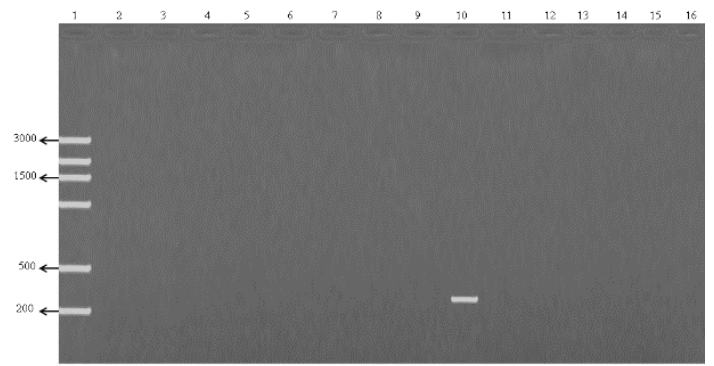

Figure 1. Tso31 nested-PCR amplification using DNA extracted from different sources. Electrophoresis was performed using 10 ul of amplification products. Lane 1 DNA ladders (solis Biodyne). Lanes 2 to 14, DNA from stool sample code A to $\mathrm{M}$. Lane 16, DNA from stool sample code $\mathrm{V}$. Lane 16, negative control.

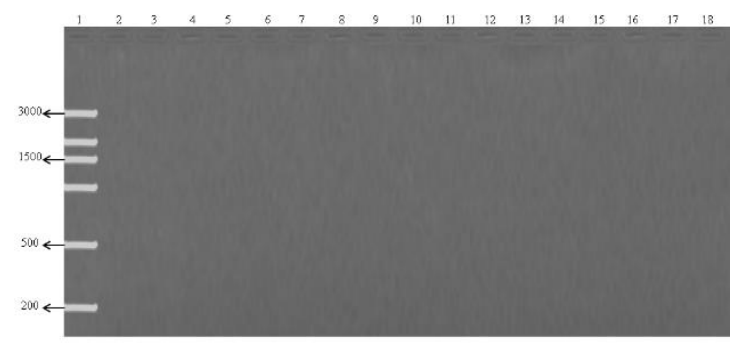

Figure 2. Tso31 nested-PCR amplification using DNA extracted from different sources. Electrophoresis was performed using 10 ul of amplification products. Lane 1 DNA ladders (solis Biodyne). Lanes 2 to 9, DNA from stool sample code $\mathrm{N}$ to $\mathrm{U}$. Lanes 10 to 17, DNA from stool sample code W to D1. Lane 18, negative control.

\section{DISCUSSION}

Molecular biology tools have been developed to detect parasites like T.solium. There are some studies have been conducted to detect T.solium using PCR based technology. Mayta et al. performed the nested PCR method using specific primers which can detect Tso31 gene in T.solium. Nested PCR can specifically amplify the DNA of T.solium without crossreacting with other parasites in the human intestine, such as $T$ saginata. Karamon et al described that nested PCR performed by Mayta et al.,(12) was the most useful method with requiring the least corrections during optimization (13). 
The specific primer that was used can detect the Tso31 gene on T.solium. This method was the best method since it does not produce cross reaction with other parasites, including parasites from Taenidae family, which may be detected in pigs (7). Tso31 is a $31.3 \mathrm{kDa}$ excretory/secretory oncosphere antigen present in T.solium. Tso31 gene is one of the most promising antigens to differentiate T.solium from $T$ saginata. Since this gene is presented in T.solium but not in T.saginata, it was recommended for differential diagnosis (14).

Verastegui et al. showed that oncosphere antigen of T.solium with molecular masses of 31.3 $\mathrm{kDa}$ is unique. This oncosphere antigen did not give reaction with other cestode infections such as T.saginata. Moreover, sera from pigs with antibodies to this oncosphere antigen did not cross react with immature T.solium, extracts from T.solium metacestodes, and T.saginata whole oncosphere (15).

Molecular methods provide a sensitive tool for identification of Taenia spp. and very useful for the accurate identification of cestode samples. Yamasaki et al. showed that molecular method like PCR can detect taeniid DNA in egg-free fecal samples where taeniid eggs are not present. They also suggested that PCR technique they had done seems to be dependent on the volume of fecal samples and the conditions of sample storage (15).

PCR method using specific primers to detect DNA in Taenia spp. has great potential in detecting T.solium. In addition, the PCR method is also relatively fast and sensitive for parasite identification $(16,17)$. The molecular method is one of the methods developed to overcome the difficulty of identifying Taenia through microscopic examination. The difficulty of distinguishing species of Taenia by microscopic examination can lead to misidentification and improper treatment (18).
Proper diagnosis of the Taenia infection can give a proper treatment. Molecular method can differentiate between strains and provides an easy method for identification of Taenia (19). Proper and accurate identification of Taenia is required for monitoring disease prevention and vector control strategies

Prevention of T.solium in pigs can be done by implementing hygienic pig farms with attention to environmental sanitation (20)(21). The pig breeders can provide cystidal drugs as anti-worm treatment (22). Precautions, control, and eradication of T.solium infection are very important. Humans can become infected with T.solium if they eat pork infected T.solium. Meat inspection in the market can be done to prevent this infection. This is so that pork circulating in the community is free from pathogens, including $T$ solium (23). Local government can give health education to community about the dangers of this infection (24). Information on how to properly cook pork needs to be socialized to the whole community $(24,25)$.

\section{CONCLUSION}

We found one sample of pig stool was positive for T.solium. This sample comes from a pig farm which has 200 pigs. This pig farm has have less stable sanitation than other farms. This indicated that pigs in Denpasar have been exposed to T.solium. Therefore, local government must take an action to prevent and eradicate of T.solium from being transmitted to humans.

\section{ACKNOWLEDGMENT}

This study was supported by Poltekkes Kemenkes Denpasar, Board for Development and Empowerment Human Resources of Health - The Ministry of Health Republic Indonesia. 


\section{CONFLICT OF INTEREST}

The authors have no conflicts of interest to declare. All co-authors have seen and agree with the contents of the manuscript. We certify that the submission is original work and is not under review at any other publication.

\section{REFERENCES}

1. Ito A, Nakao M, Wandra T. Human taeniasis and cysticercosis in Asia. Lancet. 2003;362:1918-20.

2. Okello AL, Thomas LF. Human taeniasis: current insights into prevention and management strategies in endemic countries. Risk Manag Healthc Policy. 2017;10:107-16.

3. Symeonidou I, Arsenopoulos K, Tzilves D, Soba B, Gabriël S, Papadopoulos E. Human taeniasis/cysticercosis: A potentially emerging parasitic disease in europe. Ann Gastroenterol. 2018;31(4):40612.

4. Aung AK, Spelman DW. Taenia solium Taeniasis and Cysticercosis in Southeast Asia. Am J Trop Med Hyg. 2016;94(5):947-54.

5. Ito A, Yanagida T, Nakao M. Recent advances and perspectives in molecular epidemiology of Taenia solium cysticercosis. Infect Genet Evol. 2016;40:357-67.

6. Montresor A, Palmer K. Taeniasis / cysticercosis trend worldwide and rationale for control. Parasitol Int. 2006;55:1-4.

7. Mayta H, Gilman RH, Prendergast E, Castillo JP, Tinoco YO, Garcia $\mathrm{HH}$, et al. Nested PCR for specific diagnosis of Taenia solium taeniasis. J Clin Microbiol. 2008 ;46(1):286-9.

8. Murrell KD, Dorny P, Flisser A, Geerts S, Kyvsgaard NC, Mcmanus
DP, et al. WHO / FAO / OIE Guidelines for the surveillance, prevention and control of taeniosis / cysticercosis. Murrell KD, editor. Paris; 2005.

9. Suriawanto N, Guli MM, Miswan. Deteksi Cacing Pita ( Taenia solium L .) melalui Uji Feses pada Masyarakat Desa Purwosari Kecamatan Torue. Biocelebes. 2014 ;8(1):17-28.

10. Del Brutto OH, García HH. Taenia solium Cysticercosis - The lessons of history. J Neurol Sci. 2015;359(12):392-5.

11. Qiagen. QIAamp-Fast DNA Stool Mini Kit: Quick-Start Protocol. Qiagen; 2017.

12. Karamon J, Sroka J, Cencek T, Różycki M, Chmurzyńska E, Zając $\mathrm{EB}$, et al. Optimisation and comparison of three PCR procedures for molecular identification of Taenia solium. Bull Vet Inst Pulawy. 2013;57(12):507-12.

13. Morales-Gomez MA, Gárate $\mathrm{T}$, Blocher J, Devleesschauwer B, Smit GS., Schmidt V, et al. Present status of laboratory diagnosis of human taeniosis / cysticercosis in Europe. Eur J Clin Microbiol Infect DIs. 2017;36:2029-40.

14. Vargas-calla A, Gomez-puerta LA, Lopez MT, Garcia HH, Gonzalez AE. Molecular characterization of the Taenia solium Tso31 antigen and homologous of other Taenia species from Peru. Parasitol Res. 2019;4368.

15. Verastegui M, Gilman RH, Garcia $\mathrm{HH}$, Gonzales AE, Arana Y, Jeri C, et al. Prevalence of Antibodies to Unique Taenia solium Oncosphere Antigens in Taeniasis and Human 
and Porcine Cysticercosis. Am J Trop Med Hyg. 2003;69(4):438-44.

16. Miguel González L, Montero E, Puente S, López-Velez R, Hernández M, Sciutto E, et al. PCR tools for the differential diagnosis of Taenia saginata and Taenia solium taeniasis/cysticercosis from different geographical locations. Diagn Microbiol Infect Dis. 2002 Apr;42(4):243-9.

17. Yamasaki H, Allan JC, Sato MO, Nakao M, Sako Y, Nakaya K, et al. DNA Differential Diagnosis of Taeniasis and Cysticercosis by Multiplex PCR. J Clin. 2004;42 (2):548-53.

18. Thanchomnang $\mathrm{T}$, Tantrawatpan $\mathrm{C}$, Intapan PM, Sanpool O. Rapid Molecular Identification of Human Taeniid Cestodes by Pyrosequencing Approach. PLoS One. 2014;9(6):1-7.

19. Biswal D. Molecular Methods For Diagnosis of Zoonotic Helminths : Can They Be Made Accessible to the Common Man? Adv Genet Eng. 2016;5(2):1-5.

20. Gilman RH, Gonzalez AE, Llanoszavalaga F, Tsang VCW, Garcia HH, Working C. Prevention and control of Taenia solium taeniasis / cysticercosis in Peru. Pathog Glob Health. 2012;106(5):312-8.

21. Flisser A. State of the art of Taenia solium as compared to Taenia asiatica. Korean J Parasitol. 2013;51(1):43-9.

22. Gabriël S, Dorny P, Mwape KE, Trevisan C, Braae UC, Magnussen $\mathrm{P}$, et al. Control of Taenia solium taeniasis/cysticercosis: The best way forward for sub-Saharan Africa? Acta Trop. 2016;165:252-60.
23. Bekti HS, Habibah N, Rinawati LP, Pradnya Yasa NPCD, Rindi ODG, Dewi NKAK, et al. Identifikasi Taenia solium secara Mikroskopis pada Peternakan Babi. J Kesehat. 2021 Apr;12(1):74.

24. Widarso H, Margono SS, Purba WH, Subahar R. Prevalensi dan distribusi taeniasis dan sistiserkosis. Makara, Kesehat. 2001;5(2):34-8.

25. Dharmawan NS, Swastika IK, Putra IM, Wandra T, Sutisna P, Okamoto $M$, et al. Present Situation and Problems of Cysticercosis in Animal in Bali and Papua. J Vet. 2012;13(2):154-62. 